\title{
THE IMPACT OF THE INTER-AMERICAN COURT OF HUMAN RIGHTS JURISPRUDENCE IN THE INTERNATIONAL COURT OF JUSTICE CASE LAW
}

\author{
O IMPACTO DA JURISPRUDÊNCIA DA CORTE INTERAMERICANA \\ DE DIREITOS HUMANOS NOS CASOS DA CORTE INTERNACIO- \\ NAL DE JUSTIÇA
}

Paula Wojcikiewicz Almeida*

\begin{abstract}
This article evaluates the impact of the InterAmerican Court of Human Rights (IACtHR) jurisprudence in the International Court of Justice (ICJ) case law. Based on empirical and qualitative analysis, it aims to present an overview of citations patterns in ICJ case law as far as the IACtHR is concerned. Since most external citations to IACtHR case law by the ICJ are found in individual opinions, this article will also present a qualitative analysis of the most cited issues by the most active ICJ judge with a view to identifying the functions of the judicial dialogue, as developed by AnneMarie Slaughter, which encompass (i) the general cross-fertilization function; and (ii) the function of 'enhancing the persuasiveness, authority or legitimacy of individual judicial decisions. The article intends to assess the ICJ's openness to judicial dialogue, in particular with the IACtHR.
\end{abstract}

\begin{abstract}
RESUMO
Este artigo avalia o impacto da jurisprudência da Corte Interamericana de Direitos Humanos (CtIDH) na jurisprudência da Corte Internacional de Justiça (CIJ). Com base em análise empírica e qualitativa, o objetivo é apresentar uma visão geral e analítica dos padrões de uso da jurisprudência da CtIDH nas decisões da CIJ. Como a maioria das citações externas à jurisprudência da Corte Interamericana pela CIJ é encontrada em opiniões individuais, este artigo também apresentará uma análise qualitativa dos assuntos mais frequentemente citados pelos juizes considerados 'mais ativos' da CIJ, com o objetivo de identificar as funções do diálogo judicial, conforme desenvolvido por AnneMarie Slaughter, que abrange (i) a função geral de fertilização cruzada; $e$ (ii) a função de aprimorar a capacidade de persuasão, autoridade ou legitimidade de decisões judiciais individuais. $\mathrm{O}$ artigo pretende avaliar a abertura da CIJ ao diálogo judicial, em particular com a CtIDH.
\end{abstract}

* Doctorate with honors summa cum laude in International and European Law at the Université Paris 1 Panthéon-Sorbonne (mention très honorable avec les félicitations du jury à l'unanimité, recommandé à des prix de thèse et à des subventions à la publication). Masters of Law (Master II Recherche - former DEA) in Public International and European Law - Université Paris XI, Faculté Jean Monnet. Postdoctoral visiting scholar at the Max Planck Institute for Comparative Public Law and International Law (2014). Professor of International Law, Getulio Vargas Foundation Law School in Rio de Janeiro (since 2008). Jean Monnet Chair, sponsored by the European Commission at the Getulio Vargas Foundation Law School. Associate Researcher at the Institute of International and European Law at the Sorbonne (IREDIES). Professor of International Law of the Masters in International Relations of the Faculty of Social Sciences, Getulio Vargas Foundation in Rio de Janeiro. Qualified as 'maître des conferences' in Public Law (France, CNU). Elected as Brazilian member of the International Law Association Committee on the Procedure of International Courts and Tribunals. Chair of the Interest Group on 'International Courts and Tribunals' of the Latin American Society of International Law (LASIL). Visiting professor at the École de droit de la Sorbonne, Université Paris 1 PanthéonSorbonne. E-mail: paula.almeida@fgv.br. 
KEYWORDS: Judicial Dialogue. Impact. International Court of Justice. Inter-American Court of Human Rights.
PALAVRAS-CHAVE: Diálogo judicial. Impacto. Corte Internacional de Justiça. Corte Interamericana de Direitos Humanos.

\section{INTRODUCTION}

This article evaluates the impact of the Inter-American Court of Human Rights (IACtHR) jurisprudence in the International Court of Justice (ICJ) case law. By analyzing the judicial dialogue between both courts, the objective is to assess whether the IACtHR case law provides guidance and inspiration for the solution of legal issues by the ICJ.

Importation and exportation of precedents from other ICTs is part of what has been called 'transjudicial communication'1 or 'interjudicial dialogue'. 'Interjudicial or judicial dialogue' can be broadly understood as judicial interaction, and encompasses not only an exchange of views between courts on a given subject, but also a referral and/or consideration of the decisions of other courts $^{2}$. Indeed, the dialogue between international courts occurs predominantly via external citation, which is much more a monologue than an actual dialogue since the court cited in the decision of the other court, whose precedent is being imported, will rarely have the opportunity to retort or to engage in any kind of exchange of views ${ }^{3}$.

However, it is not uncommon that courts draw on the opinion of other courts without express attribution ${ }^{4}$. It has already been argued that the absence of express reference is not a determining factor in the lack of influence ${ }^{5}$. The author is aware that the analysis of direct referral to external case law via quantitative research methods has proven to be an unrealistic measure of the extent of judicial dialogue, and must be supplemented with qualitative approaches, such as the deep evaluation of both direct and indirect citation of external case law ${ }^{6}$. ICTs, in particular the ICJ, may borrow the idea without publicizing its source ${ }^{7}$, as it seemingly did in the cases concerning consular assistance ${ }^{8}$. More recently, in

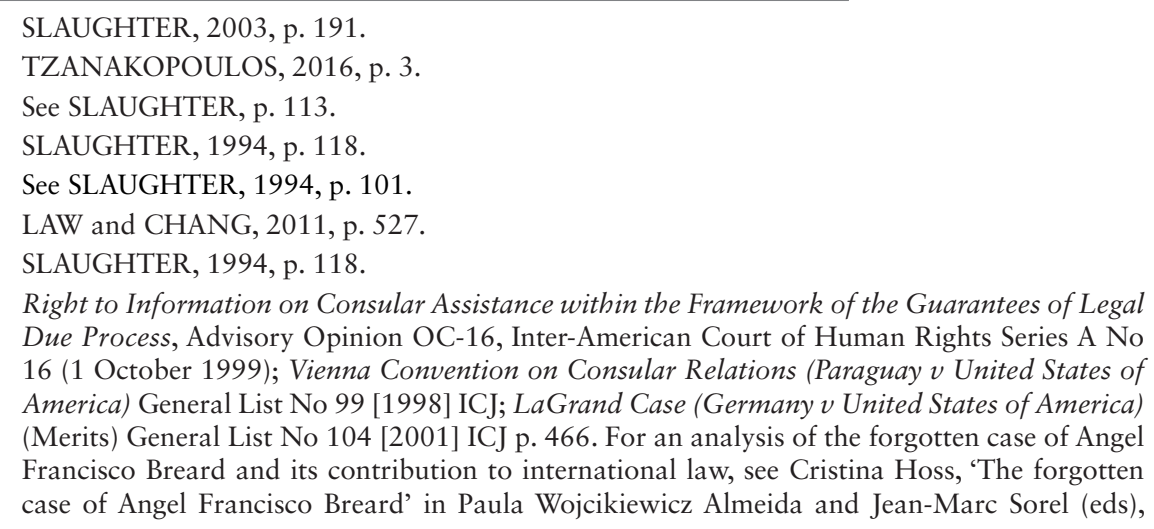
Due Process, Advisory Opinion OC-16, Inter-American Court of Human Rights Series A No 16 (1 October 1999); Vienna Convention on Consular Relations (Paraguay v United States of America) General List No 99 [1998] ICJ; LaGrand Case (Germany v United States of America) (Merits) General List No 104 [2001] ICJ p. 466. For an analysis of the forgotten case of Angel Francisco Breard and its contribution to international law, see Cristina Hoss, 'The forgotten case of Angel Francisco Breard' in Paula Wojcikiewicz Almeida and Jean-Marc Sorel (eds), 
the Certain Activities case, the Court did not explicitly mention European and Inter-American Court of human rights case law, but appears to have generally followed its development for the purposes of awarding compensation 9 .

Taking this context into account, for methodological reasons, this article will only focus on the use of external case law via direct referral. 'Judicial dialogue' will be understood as 'indirect' horizontal dialogue or formal interaction or communication between international courts at the same hierarchical level ${ }^{10}$. ICTs constantly refer to judgments of other courts with multiple purposes: to define or illustrate applicable standards and concepts; to assist in the interpretation of parallel rules; to help fill in gaps; to confirm the Court's decision; and search for guidance or inspiration, among others ${ }^{11}$. Overall, the most frequent rationale advanced by judges for justifying the need to look abroad concerns the improvement of the quality of their decisions ${ }^{12}$, by providing 'a broader range of ideas and experience that makes for better, more reflective opinions ${ }^{\text {'13 }}$. Also, it seems that in especially controversial or politically sensitive cases, judges tend to look consistently to other prestigious and influential courts in order to search for guidance, inspiration and to confer legitimacy on their decisions ${ }^{14}$.

As far as the ICJ is concerned, the empirical analysis of the impact of the IACtHR jurisprudence aims to identify the functions of the judicial or 'transjudicial' dialogue, as developed by Anne-Marie Slaughter, which encompass (i) the general cross-fertilization function, by providing 'inspiration for the solution of a particular legal problem'; and (ii) the function of 'enhancing the persuasiveness, authority or legitimacy of individual judicial decisions ${ }^{15}$.

No doubt remains that the ICJ has played a significant role in the development of the international protection of human rights ${ }^{16}$. After a so-called first phase marked by 'hesitation and constraint', to borrow Simma's words, the

Latin America and the ICJ: Contributions to International law (Routledge 2016).

9 See Certain Activities Carried Out by Nicaragua in the Border Area (Costa Rica v. Nicaragua) (Compensation (Separate Opinion of Judge Cançado Trindade) General List No 150 [2018] ICJ par. 42, 29-32.

10 SLAUGHTER, 1994, p. 103.

11 See KOH, 2004, p. 43-57.

12 VOETEN, 2010, p. 550.

13 SLAUGHTER, 2003, p. 201.

14 LAW and CHANG, 2011, p. 571.

15 SLAUGHTER, 1994, p. 117-19.

16 The PCIJ had also made a contribution to the protection of minority rights, for example, in the following cases: Certain Questions Relating to Settlers of German Origin in the Territory Ceded by Germany to Poland (Advisory Opinion) PCIJ Rep 1923 Series B No 6; Rights of Minorities in Upper Silesia (Germany v Poland) PCIJ Rep 1928 Series A No 15; Treatment of Polish Nationals and Other Persons of Polish Origin or Speech in Danzing Territory (Advisory Opinion) PCIJ Rep 1932 Series A/B No 44; and Minority Schools in Albania (Advisory Opinion) PCIJ Rep 1935 Series A/B No 64. 
ICJ has indeed become more concerned with human rights in recent years ${ }^{17}$. This is maybe due, among other factors, to a change of judicial culture (including State's submissions to the Court $)^{18}$ and to the presence of judges with strong backgrounds in human rights ${ }^{19}$. Topics such as reservations to human rights treaties ${ }^{20}$ and the concept of self-determination ${ }^{21}$ illustrate the Court's long-standing commitment to human rights and the practice of referencing the work of human rights treaty bodies in its judgments ${ }^{22}$.

ICJ's more recent case law appears, though, to revel a 'qualitative leap' as far as human rights are concerned, such as the Nuclear Weapons Advisory Opinion (1996) ${ }^{23}$, the Wall Opinion (2004) ${ }^{24}$, Congo v. Uganda (2005) $)^{25}$, Congo v. Rwanda $(2006)^{26}$, the Genocide Cases - Bosnia-Herzegovina v. Serbia $(2007)^{27}$ and Croatia v. Serbia (2015) ${ }^{28}$; Georgia v. Russia (2011) ${ }^{29}$; and Belgium v. Senegal (2009). Latest cases featuring a human rights dimension comprise Ukraine $v$. Russian Federation (submitted in 2017) ${ }^{30}$ and Qatar v. United Arab Emirates

17 See SIMMA, 2013, p. $579-585$.

18 For instance, in the Preliminary Objections in the case opposing Nicaragua to Colombia, the former referred to the law and practice of the IACtHR. See Alleged Violations of Sovereign Rights and Maritime Spaces in the Caribbean Sea (Nicaragua v. Colombia) (Preliminary Objections) General List No 155 [2016] ICJ, p. 39.

19 See HIGGINS, 2007, p. 746; CROOK, 2004, p. 7; NEUMAN, 2011, p. 102.

20 Armed Activities on the Territory of the Congo (Democratic Republic of the Congo v. Rwanda) (Jurisdiction and Admissibility (Merits) General List No 126 [2006], p. 6; and Armed Activities on the Territory of the Congo (Democratic Republic of the Congo $v$. Rwanda) (Jurisdiction and Admissibility (Joint Separate Opinion of Judges Higgins, Kooijmans, Elaraby, Owada, and Simma) General List No 126 [2006] ICJ.

21 South West Africa Cases (Ethiopia v South Africa) (Liberia v South Africa) (Merits) General List No 46 and 47 [1966] ICJ; Legal Consequences for States of the Continued Presence of South Africa in Namibia (South West Africa) notwithstanding Security Council Resolution 276 (Advisory Opinion) General List No 53 [1971] ICJ; Western Sahara (Advisory Opinion) General List No 61 [1975] ICJ.

22 HIGGINS, 2007, p. 746-748.

23 Legality of the Threat or Use of Nuclear Weapons (Advisory Opinion) General List No 95 [1996] ICJ p. 226.

24 Legal Consequences of the Construction of a Wall in the Occupied Palestinian Territory (Advisory Opinion) General List No 131 [2004] ICJ p. 136.

25 Armed Activities on the Territory of the Congo (Democratic Republic of the Congo $v$ Uganda) (Merits) General List No 116 [2005] ICJ p. 168.

26 Armed Activities on the Territory of the Congo (Democratic Republic of the Congo $v$. Rwanda) (Jurisdiction and Admissibility) General List No 126 [2006] ICJ, p. 6.

27 Application of the Convention on the Prevention and Punishment of the Crime of Genocide (Bosnia and Herzegovina v. Serbia and Montenegro) General List No 91 [2007] ICJ, p. 43.

28 Application of the Convention on the Prevention and Punishment of the Crime of Genocide (Croatia v. Serbia) (Merits) General List No 118 [2015] ICJ, p. 3.

29 Application of the International Convention on the Elimination of All Forms of Racial Discrimination (Georgia $v$. Russian Federation) (Preliminary Objections (Dissenting Opinion of Judge Cançado Trindade) General List No 140 [2011] ICJ, p. 70.

30 Application of the International Convention for the Suppression of the Financing of Terrorism and of the International Convention on the Elimination of All Forms of Racial Discrimina- 
(submitted in 2018) ). $^{31}$.

In spite of ICJ's significant role in the development of the international protection of human rights, it appears to be acting cautiously in the practice of cross-fertilization with other ICTs and commissions ${ }^{32}$. Based on empirical analysis, the first part of this article will present an overview of citation patterns in the ICJ case law with reference to the jurisprudence of the IACtHR (I). Considering that most external citations to IACtHR case law by the ICJ can be found in individual opinions, the second part of this research will focus on the individual opinions of the most active ICJ judge as far as cross fertilization is concerned, as well as its contribution to international law (II).

\section{CITATION PATTERNS: AN OVERVIEW}

There are only a few discernible examples in which the ICJ has taken into consideration the contribution of the Inter-American Courts of Human Rights in its judgments or in separated opinions. On one hand, the apogee of human rights protection at the ICJ is indubitably marked by the Diallo case, the sole example of direct judicial dialogue with the IACtHR in a majority judgment. (A). As celebrated by Simma, 'the human rights rose like a phoenix from the ashes of the Diallo case' ${ }^{33}$. The Diallo judgment on merits motivated judge Cançado Trindade to qualify the current time as 'the new era of international adjudication of human rights cases by the ICJ'34. On the other hand, most references to IACtHR case law are found in the individual opinions of judges, that can interpreted as a push for a more expansive approach in the ICJ (B).

\section{A. JUDGMENT: DIALLO CASE AND THE MAJORITY'S CONSER- VATIVE APPROACH}

The Diallo case represents the first time that the World Court has expressly taken into account the contribution of both the European and the Inter-American Courts of Human Rights, albeit regrettably without mentioning any specific case law. In paragraph 68 of the judgment on merits (30.11.2010), the Court referred to the interpretation held by the European and the Inter-American Courts in relation to, respectively, Art. 1 of the Protocol No. 7 to the European Convention

tion (Ukraine v. Russian Federation) (Provisional Measures Order (Separate Opinion od Judge Cançado Trindade) General List No 166 [2017] ICJ, p. 104.

31 Application of the International Convention on the Elimination of all Forms of Racial Discrimination (Qatar v. United Arab Emirates) (Provisional Measures Order (Separate Opinion of Judge Cançado Trindade) General List No 172 [2018] ICJ.

32 HIGGINS, 2007, p. 749.

33 SIMMA, 2013, p. 593.

34 Application of the International Convention on the Elimination of All Forms of Racial Discrimination (Qatar v. United Arab Emirates) (Provisional Measures Order (Separate Opinion of Judge Cançado Trindade) General List No 172 [2018] ICJ, par. 7-8. 
for the Protection of Human Rights and Fundamental Freedoms, and Art. 22, par. 6 of the American Convention on Human Rights. The Court 'notes', in a rather loose manner, that the said provisions are 'close in substance to those of the Covenant and the African Charter which the Court is applying in the present case' and is regarded as consistent with what it has found in paragraph 65 of the judgment; i.e., the prohibition of arbitrary expulsion ${ }^{35}$. In their joint declaration, judges Greenwood and Keith pointed out that the majority judgment went beyond the jurisprudence of human rights courts cited by the ICJ, which was limited to conferring procedural guarantees ${ }^{36}$. This demonstrates the Court's willingness to ensure the coherence of international law as it took into account the interpretation given by human rights tribunals and quasi-judicial bodies ${ }^{37}$. In this case, the formal judicial dialogue engaged with the IACtHR revealed a supportive function and clearly served to confirm the ICJ's decision ${ }^{38}$.

However, a more concrete indication of the ICJ's intent to engage in a horizontal dialogue of Courts can be found in the 2012 judgment on compensation. The judgment has been lauded as remarkable since it is the second time in the history of the ICJ that it has fixed an amount of compensation; the first being the Corfu Channel case (1949) ${ }^{39}$. The judgment is indeed notable, in particular for the purposes of this research, because the Court relied extensively on decisions of other ICTs to determine the amount of compensation, namely on case law by the European and Inter-American courts of human rights; the Iran-US Tribunal; and the International Tribunal for the Law of the Sea ${ }^{40}$. The Court took into account the practice of other courts, tribunals and commissions, 'which have applied general principles governing compensation when fixing its amount' in the cas de espèce $e^{41}$. This was clearly to avoid inconsistent and contradictory jurisprudence. Although the ICJ mentioned the Inter-American Court, this was merely included in a non-exhaustive list of other courts, tribunals and commissions.

35 Abmadou Sadio Diallo (Republic of Guinea v. Democratic Republic of the Congo) (Merits) General List No 103 [2010] ICJ, p. 664.

36 See Abmadou Sadio Diallo (Republic of Guinea v. Democratic Republic of the Congo) (Merits (Joint Declaration of Judges Greenwood and Keith) General List No 103 [2010] ICJ, par. 14.

37 EL BOUDOUHI, 2010, p. 282-3.

38 Ver, no geral, DE BRABANDERE, 2016, p. 15.

39 Corfu Channel case (UK v. Alb.), Assessment of Amount of Compensation, Judgment, I.C.J. Rep 1949, 244. For examples in which the ICJ awarded other forms of reparation for human rights and humanitarian law violations, see Gentian Zyberi, 'The International Court of Justice and applied forms of reparation for international human rights and humanitarian law violations' [2011] 7 Utrecht Law Review 1, 204.

40 Abmadou Sadio Diallo Case (Republic of Guinea $v$ Democratic Republic of the Congo) (Compensation) General List No 103 [2012] ICJ, par. 13.

41 Abmadou Sadio Diallo Case (Republic of Guinea $v$ Democratic Republic of the Congo) (Compensation) General List No 103 [2012] ICJ, par. 13. 
When considering claims for compensation for non-material injury suffered by Mr. Diallo, comprising mental and moral damage, the ICJ cited IACtHR case law, in particular Gutiérrez-Soler v. Colombia, to state that '[n]on pecuniary damage may include distress, suffering, tampering with the victim's core values, and changes of a non-pecuniary nature in the person's everyday life ${ }^{\prime 42}$. Such damage, according to the ICJ, could be established without specific evidence (par. 21). In order to quantify compensation for non-material injury, the Court relied on equitable considerations also extracted from the practice of other ICTs and commissions, in particular the European and the Inter-American court of human rights (par. 24). The ICJ cited the case Cantoral Benavides v. Peru to illustrate that equity plays a fundamental role in the definition of such quantification ${ }^{43}$.

As far as material injury is concerned, the Court examined three heads of damage (loss of personal property, of income and of potential earnings). The ICJ cited IACtHR case law, among others, on three distinct occasions: first, in order to justify its reliance on equitable considerations for the purposes of awarding an amount of compensation ${ }^{44}$; second, to consider that claims for loss of income are cognizable as a component of compensation ${ }^{45}$; and, third, to deny the purely speculative character of amounts of lost income and post-expulsion remuneration, which are to be estimated whenever they cannot be calculated precisely ${ }^{46}$.

Finally, the Court referred to case law from other ICTs, including the IACtHR, to demonstrate that 'the award of post -judgment interest is consistent with the practice of other international courts and tribunals' and to justify its

42 Gutiérrez-Soler Case (Merits, Reparations and Costs) Inter-American Court of Human Rights Series C No 132 (12 September 2005) para. 82, cited by the Abmadou Sadio Diallo Case (Republic of Guinea $v$ Democratic Republic of the Congo) (Compensation) General List No 103 [2012] ICJ par. 18.

43 Cantoral Benavides (Reparations and Costs) Inter-American Court of Human Rights Series C No 88 (2 December 2001), para. 53, cited by the Abmadou Sadio Diallo Case (Republic of Guinea v Democratic Republic of the Congo) (Compensation) General List No 103 [2012] ICJ, par. 24.

44 Chaparro Álvarez and Lapo Íñiguez Case (Preliminary Objections, Merits, Reparations and Costs Judgment) Inter-American Court of Human Rights Series C No 170 (21 November 2007) paras. 240 and 242, cited by the Abmadou Sadio Diallo Case (Republic of Guinea $v$ Democratic Republic of the Congo) (Compensation) General List No 103 [2012] ICJ, par. 33.

45 Suárez Rosero Case (Reparations and Costs Judgment) Inter- American Court of Human Rights Series C No 44(20 January 1999), para. 60, cited by the Abmadou Sadio Diallo Case (Republic of Guinea $v$ Democratic Republic of the Congo) (Compensation) General List No 103 [2012] ICJ, par. 40.

46 "Street Children" Case (Reparations and Costs Judgment) Inter-American Court of Human Rights Series C No 77 (26 May 2001), para. 79, cited by Ahmadou Sadio Diallo Case (Republic of Guinea $v$ Democratic Republic of the Congo) (Compensation) General List No 103 [2012] ICJ, par. 40; and Chaparro Álvarez and Lapo Íñiguez Case (Preliminary Objections, Merits, Reparations and Costs Judgment) Inter-American Court of Human Rights Series C No 170 (21 November 2007), paras. 235-236, cited by the Abmadou Sadio Diallo Case (Republic of Guinea v Democratic Republic of the Congo) (Compensation) General List No 103 [2012] ICJ, par. 49. 
decision to award post-judgment interest at an annual rate of $6 \%$ if the payment of compensation is delayed ${ }^{47}$.

This decision is relevant to this research due to the Court's substantial reliance on decisions by other ICTs and commissions ${ }^{48}$. The practice of ICTs and commissions was used as a resource for the Court to develop principles for awarding compensation ${ }^{49}$. For the first time, the ICJ has expressly relied on IACtHR case law on majority judgments and did so with very specific purposes: to define applicable standards and concepts, as well as to seek guidance and inspiration in the field of human rights litigation on setting amounts of compensation. This is because the ICJ, in its previous case law on compensation, namely the Corfu Channel case, did not make its own evaluation, but instead limited itself to checking via an expert opinion if the amount of compensation claimed by the UK was 'well founded in fact and law', according to Art. 53, par.2, of the Statute ${ }^{50}$. Hence, the Court has every reason to look abroad since 'there is very little in its own jurisprudence on which it can draw's1. In addition, the practice of other ICTs and commissions, notably the IACtHR, seems to have motivated the ICJ to fix a substantially high amount of compensation when compared to previous judgments for similar wrongs ${ }^{52}$.

One might wonder whether the awarding of compensation by the ICJ could be linked to the nature of the claim; i.e., those involving 'fundamental' human rights violations, as the Court seems to indicate in a passage of the Diallo's judgment on merits ${ }^{53}$. Or, more generally, will the ICJ increasingly fix the amount of compensation in future cases other than those connected to diplomatic protection $^{54}$ ? These questions will inevitably touch upon the matter of what extent precedents from other ICTs and commissions are used in inter-State practice.

47 Bámaca Velásquez Case (Reparations and Costs Judgment) Inter-American Court of Human Rights Series C No 91 (22 February 2002), para. 103, cited by the Abmadou Sadio Diallo Case (Republic of Guineav Democratic Republic of the Congo) (Compensation) General List No 103 [2012] ICJ, par. 56.

48 GIORGETTI, 2012, p. 739.

49 ULFSTEIN, 2013, p. 484-485.

50 See Corfu Channel (U.K. v. Albania) General List No 1 [1949] ICJ, para 244.

51 Abmadou Sadio Diallo (Republic of Guinea v. Democratic Republic of the Congo) (Compensation (Declaration of Judge Greenwood) General List No 103 [2012] ICJ par. 8.

52 Judge Greenwood argued that the sum awarded by the Court concerning Diallo's non material injury far exceeded the level awarded by the European and Inter-American Courts of Human Rights. See Abmadou Sadio Diallo (Republic of Guinea v. Democratic Republic of the Congo) (Compensation (Declaration of Judge Greenwood) General List No 103 [2012] ICJ par 9.

53 Abmadou Sadio Diallo (Republic of Guinea v. Democratic Republic of the Congo) (Merits) General List No 103[2010] ICJ p. 639 par. 161.

54 ULFSTEIN, 2013, p. 479-480. Other ICTs and commissions that have awarded compensation in inter-State cases include the Eritrea-Ethiopia Claims Commission, the United Nations Compensation Commission (UNCC), and the ITLOS's M/V Saiga case. 
Although not referring directly to IACtHR's jurisprudence, the ICJ judgment on compensation in the case Certain Activities carried out by Nicaragua in the Border Area (Costa Rica v. Nicaragua) seems to confirm the latter hypothesis according to which the ICJ seems more inclined to fix compensation awards regardless of the subject matter. This is the first case in which the ICJ has ever awarded compensation for environmental damage ${ }^{55}$.

\section{B. SEPARATE OPINIONS: THE PUSH FOR A MORE EXPANSIVE APPROACH}

Most external citations to IACtHR case law by the ICJ can be found in separate opinions. The figure below indicates that most references to IACtHR case law are found in judgments on merits $(48 \%)$, which represents 12 referrals to IACtHR case law among which 8 separate opinions, 3 dissenting opinions and one majority judgment. Of the total separate opinions that make reference to IACtHR case law, most are found in judgments on merits and provisional measures. Of the total dissenting opinions that refer to IACtHR case law, most are found in judgments on preliminary objections and merits.

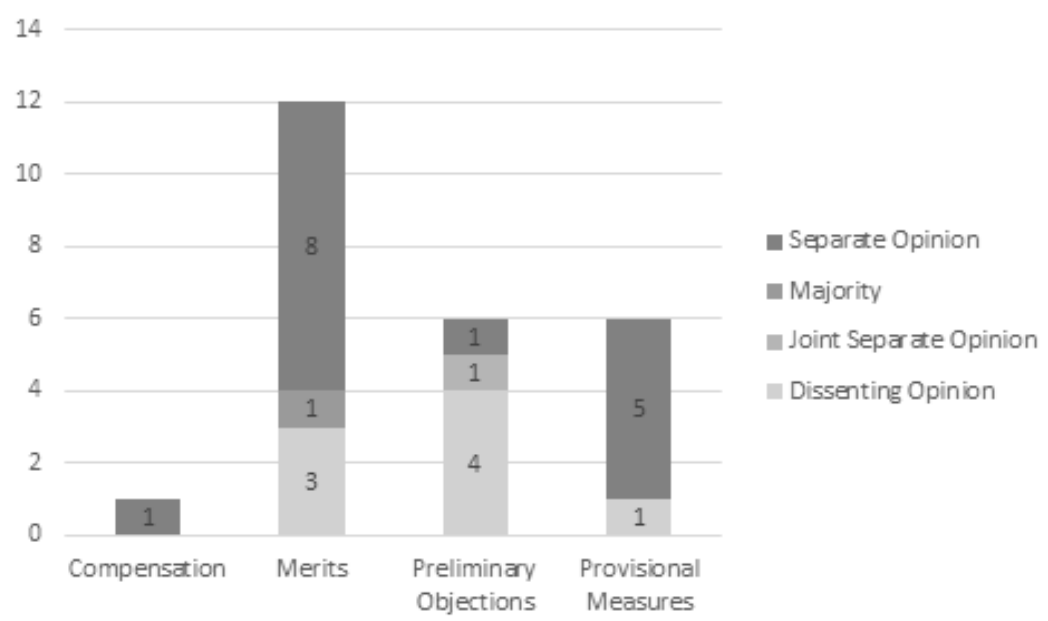

The survey identified all references to the IACtHR by individual judges in their individual opinions. References to IACtHR case law by the ICJ can be found in the separate and dissenting opinions of Judge Cançado Trindade; in the separate opinion of judge Higgins ${ }^{56}$; in the Joint separate opinion of Judges

55 Certain Activities Carried Out by Nicaragua in the Border Area (Costa Rica v. Nicaragua) (Compensation (Separate Opinion of Judge Cançado Trindade) General List No 150 [2018] ICJ, par. 41-42.

56 Oil Platforms Case (Islamic Republic of Iran v. United States of America) (Merits (Separate Opinion of Judge Higgins) General List No 90 [2003] ICJ, para 33, p. 234. 
Higgins, Kooijmans, Elaraby, Owada and Simma ${ }^{57}$; in the Dissenting opinion of Judge ad hoc Paolillo ${ }^{58}$; in the Separate opinions of Judge ad hoc Kreka ${ }^{59}$; and in the Dissenting opinion of Judge ad hoc Mahiou ${ }^{60}$, as can be seen in the graph below.

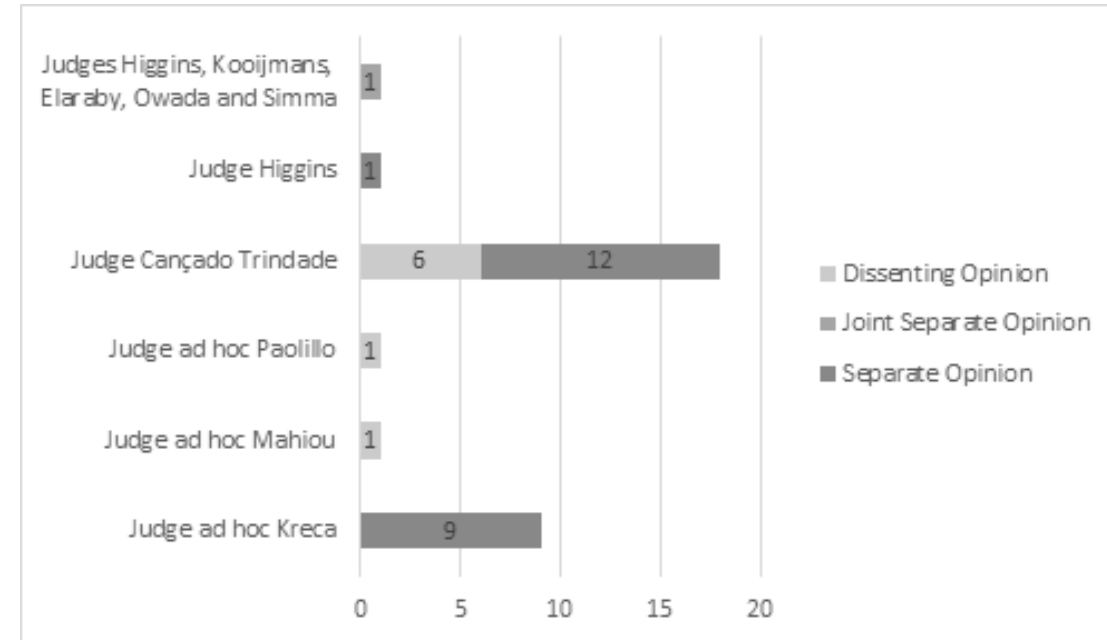

As extracted from the figure above, there are more references to IACtHR case law in separate opinions than in dissenting opinions. The most activist judges as far as cross-fertilization with IACtHR case law is concerned are Judge Cançado Trindade (18 references), Judge ad hoc Kreka (2 references) and Judge Higgins (2 references).

57 Armed Activities on the Territory of the Congo (Democratic Republic of the Congo v. Rwanda) (Preliminary Objections (Joint Separate Opinion of Judges Higgins, Kooijmans, Elaraby, Owada and Simma) General List No 126 [2006] ICJ, paras 12, 15.

58 Application for Revision of the Judgment of 11 September 1992 in the Case concerning the Land, Island and Maritime Frontier Dispute (El Salvador v. Honduras), (Merits (Dissenting Opinion of Judge ad hc Paolillo) General List No 127 [2003] ICJ, para 33.

59 Legality of Use of Force (Serbia and Montenegro v. United Kingdom) (Preliminary Objections (Separate Opinion of Judge ad hoc Kreca) General List No 113 [2004] ICJ; Legality of Use of Force Case (Serbia and Montenegro v Portugal) (Preliminary Objections (Separate Opinion of Judge ad hoc Kreca) General List no 111 [2004] ICJ; Legality of Use of Force Case (Serbia and Montenegro $v$ Netherlands) (Preliminary Objections (Separate Opinion of Judge ad hoc Kreca) General List No 110 [2004] ICJ; Legality of Use of Force (Serbia and Montenegro v Italy) (Preliminary Objections (Separate Opinion of Judge ad hoc Kreca) General List No 109 [2004] ICJ; Legality of Use of Force (Serbia and Montenegro $v$ Germany) (Preliminary Objections (Separate Opinion of Judge ad hoc Kreca) General List No 108 [2004] ICJ; Legality of use of Force Case (Serbia and Montenegro v France) (Preliminary Objections (Separate Opinion of Judge ad hoc Kreca) General List No 107 [2004] ICJ; Legality of Use of Force Case (Serbia and Montenegro $v$ Belgium) (Preliminary Objections (Separate Opinion of Judge ad hoc Kreca) General List No 105 [2004] ICJ, para 10.

60 Ahmadou Sadio Diallo (Republic of Guinea v. Democratic Republic of the Congo) (Merits (Dissenting Opinion of Judge ad hoc Mahiou) General List No 103 [2010] ICJ, page 825-26. 
The findings may suggest that ideology matters: activist ICJ judges who are more inclined toward an expansive interpretation of international law and, specifically of human rights, are more likely to use external citations than 'conservative' judges ${ }^{61}$. External precedents may be more useful for a judge to justify a broad interpretation of international law than for a judge who engages in a narrower interpretation ${ }^{62}$. In other words, more activist judges are more likely to cite external sources ${ }^{63}$.

Such an inclination towards an expansive reading of international human rights may derive from the background of judges ${ }^{64}$. As pointed out by Higgins, some judges with strong backgrounds in human rights included Kooijmans, Buergenthal and Simma ${ }^{65}$. Among the current members with backgrounds in human rights: judges Cançado Trindade, Abraham, Robinson and, most recently, judge Iwasawa.

The education and professional background of the judges often shape their decision-making process. Indeed, there is a relationship between judicial background and foreign or international law and case law usage ${ }^{66}$. The movement of personnel from the Inter-American system to the universal system reflects this trend, as can be seen from the practice of Judge Cançado Trindade.

\section{JUDGE CANÇADO TRINDADE'S SEPARATE OPINIONS: THE IACTHR CASE LAW AS GUIDANCE AND INSPIRATION FOR THE ICJ}

Judge Antônio Augusto Cançado Trindade moved from the Inter-American Court (1995-2006) to the ICJ (2009) and brought specific knowledge and experience acquired from the regional system to the ICJ and also a general receptivity to human rights developments ${ }^{67}$. His opinions frequently cite the case law of the Inter-American Court for drawing lessons or for importing applicable solutions.

This formal judicial dialogue has taken place across diverse subjects, encompassing both procedural and substantive issues. In the referred areas, the IACtHR has adopted innovative approaches and established important precedents which may be exported to other international courts regardless of their judicial identity $^{68}$. This formal judicial dialogue has taken place across diverse subjects,

61 VOETEN, 2010, p. 567-8.

62 VOETEN, 2010, p. 553 and 567.

63 VOETEN, 2010.

64 VOETEN, 2010, p. 567.

65 See HIGGINS, 2007, p. 746; CROOK, 2004, p. 7; NEUMAN, 2011, p. 102.

66 See ALMEIDA, 2019.

67 NEUMAN, 2011, p. 102. See NUBBERGER, 2017, p. 422.

68 See PASQUALUCCI, 1995, p. 24. 
encompassing both procedural and substantive issues, including: access to justice (A); provisional measures (B); evidence and burden of proof $(\mathrm{C})$; interpretation of human rights treaties $(\mathrm{D})$; material scope of jus cogens $(\mathrm{E})$; and reparations $(\mathrm{F})$.

\section{A) ACCESS TO JUSTICE}

The first issue concerns access to justice. This topic is frequently referred to in the separate opinions of Judge Cançado Trindade ${ }^{69}$. He cites IACtHR case law with a view to promoting an expansive approach to access to justice and to overcoming procedural obstacles ${ }^{70}$. In his view, expanding both formal and effective access to justice entail not only the exercise of the right of access to a court (right to individual petition), but also the participation in the proceedings, due process of law and 'equality of arms'. According to Cançado Trindade, access to justice latu sensu also encompasses the reparations owed to victims ${ }^{71}$. Developments such as these were not shared by the majority judgment, which seems to have ignored IACtHR case law brought by the Brazilian judge.

69 Judgment No. 2867 of the Administrative Tribunal of the International Labour Organization upon a Complaint Filed against the International Fund for Agricultural Development (Advisory Opinion (Separate Opinion of Judge Cançado Trindade) General List No 146 [2012] ICJ, 51, paras 67, 75, 91, 96-99; Jurisdictional Immunities of the State (Germany v. Italy: Greece intervening) (Merits (Dissenting Opinion of Judge Cançado Trindade) General List No 143 [2012] ICJ, p. 179, paras 61, 62, 205-211, 216-217.

70 Hilare, Constantine and Benjamin et al. Case (Merits, Reparations and Costs) Inter-American Court of Human Rights Series C No 94 (21 June 2002); Loayza Tamayo Case (Merits) InterAmerican Court of Human Rights Series C No 33 (17 September 1997); Juan Humberto Sánchez Case (Preliminary Objections, Merits, Reparations and Costs) Inter-American Court of Human Rights Series C No 99 (7 June 2003); Cantoral Benavides Case (Merits) Inter-American Court of Human Rights Series C No 69 (18 August 2000) para 112; Castillo Petruzzi et al. Case (Compliance with Judgment) Inter-American Court of Human Rights Series C No 59 (17 November 1999), para 128; Maritza Urrutia Case (Merits, Reparations and Costs) Inter-American Court of Human Rights Series C No 103 (27 November 2003), para 128; The Right to Information on Consular Assistance in the Framework of the Guarantees of the Due Process of Law, Advisory Opinion OC-16, Inter-American Court of Human Rights Series A No 16 (1 October 1999); Plán de Sánchez Massacre Case (Merits) Inter-American Court of Human Rights Series C No 105 (29 April 2004; Mapiripán Massacra Case (Merits, Reparations and Costs) Inter-American Court of Human Rights Series C No 134 (15 September 2005); Ituango Massacres Case (Preliminary Objections, Merits, Reparaltions and Costs) Inter-American Court of Human Rights Series C No 148 (1 July 2006); Almonacid Arellano et al Case (Preliminary Objections, Merits, Reparations and Costs) Inter-American Court of Human Rights Series C No 154 (26 September 2006); Miguel Castro-Castro Prision Case (Merits, Reparations and Costs) InterAmerican Court of Human Rights Series C No 160 (25 November 2006); La Catunta Case (Merits, Reparations and Costs) Inter-American Court of Human Rights Series C No 162 (29 November 2006); Goiburú et al Case Merits, Reparations and Costs) Inter-American Court of Human Rights Series C No 153 (22 September 2006).

71 Abmadou Sadio Diallo (Republic of Guinea v. Democratic Republic of the Congo) (Compensation (Separate Opinion of Judge Cançado Trindade) General List No 103 [2012] ICJ p. 38283 , para 95. 


\section{B) PROVISIONAL MEASURES}

The second issue concerns provisional measures. Judge Cançado Trindade has taken jurisprudential inspiration in the IACtHR ${ }^{72}$ in the following ICJ cases: Request for Interpretation in the case concerning the Temple of Preah Vihear ${ }^{73}$, Certain Activities Carried Out by Nicaragua in the Border Area and Construction of a Road ${ }^{74}$, and Ukraine v. Russian Federation ${ }^{75}$. On these occasions, the Court granted provisional measures in order to ensure the effectiveness of its ultimate decisions, as well as the proper administration of justice. Cançado Trindade stressed courts inherent power to indicate provisional measures, which would be also applicable to the ICJ, and ultimately, the need to recognize their autonomous legal regime with all its related consequences ${ }^{76}$, as affirmed by the IACtHR case law $^{77}$. Moreover, judge Cançado juxtaposes the plausibility test (of state rights)

72 For the IACtHR practice, see, for example, Haitians and Dominicans of Haitian-origin in the Dominican Republic Matter (Provisional Measures Order) Inter-American Court of Human Rights (7 September 2012), paras 5-6; Blake Case (Merits) Inter-American Court of Human Rights Series C No 36 (24 January 1998); Bámaca Velásquez Case (Reparations and Costs) Inter-American Court of Human Rights Series C No 91 (22 February 2002); Moiwana Community Case (Preliminary Objections, Merits, Reparations and Costs) Inter-American Court of Human Rights Series C No 124 (15 June 2005); Moiwana Community Case (Interpretation of the Judgment of Merits, Reparations and Costs) Inter-American Court of Human Rights Series C No 145 (8 February 2006); Miguel Castro Castro Prison Case (Merits, Reparations, and Costs Judgment) Inter-American Court of Human Rights Series C Series C No 160 (25 November 2006).

73 Request for Interpretation of the Judgment of 15 June 1962 in the Case concerning the Temple of Preah Vihear (Cambodia v. Thailand) (Provisional Measures Order (Separate Opinion of Judge Cançado Trindade) General List No 151 [2011] ICJ, paras 11, 26; Request for Interpretation of the Judgment of 15 June 1962 in the Case concerning the Temple of Preah Vihear (Cambodia v. Thailand) (Provisional Measures Order (Separate Opinion of Judge Cançado Trindade) General List No 151 [2011] ICJ, paras 32, 50.

74 Case concerning the Construction of a Road in Costa Rica Along the San Juan River (Nicaragua $v$ Costa Rica) (Merits (Separate Opinion of Judge Cançado Trindade) General List No 152 [2015] ICJ para 11, 12, 62

75 Application of the International Convention for the Suppression of the Financing of Terrorism and of the International Convention on the Elimination of All Forms of Racial Discrimination (Ukraine v. Russian Federation) (Provisional Measures Order (Separate Opinion of Judge Cançado Trindade) General List No 166 [2017] ICJ, para 6, 8, 9, 10, 18.

76 Certain Activities Carried Out by Nicaragua in the Border Area (Costa Rica v. Nicaragua) and Case concerning the Construction of a Road in Costa Rica Along the San Juan River (Nicaragua $v$ Costa Rica) (Merits (Separate Opinion of Judge Cançado Trindade) General List No 152 [2015] ICJ para 33-44, 60-66. See also Application of The International Convention On The Elimination Of All Forms Of Racial Discrimination (Qatar V. United Arab Emirates) (Provisional Measures Order (Separate Opinion of Judge Cançado Trindade) General List No 172 [2018] ICJ, para 76, 95; Alleged Violations of the 1955 Treaty of Amity, Economic Relations, and Consular Rights (Islamic Republic Of Iran V. United States Of America) (Provisional Measures Order (Separate Opinion of Judge Cançado Trindade) General List No 175 [2018] ICJ para 95.

77 Eloísa Barrios et al regarding Venezuela Matter (Provisional Measures Order) Inter-American Court of Human Rights (29 June 2005), paras 4-11; Communities of Jiguamiandó and Curbaradó regarding Colombia Matter (Provisional Measures Order) Inter-American Court of 
versus human vulnerability, referring to the case law of the IACtHR in the context of extreme vulnerability of the victims amidst the decomposition of the public power and forced displacement of members of indigenous communities amidst chronic poverty ${ }^{78}$. This position echoed in the doctrine that recognized the need to take into account the vulnerability of the victims as forming part of the plausibility test, although not replacing $i^{79}$. Such reasoning, however, was not followed by the Court's majority.

\section{C) EVIDENCE AND BURDEN OF PROOF}

The third issue relates to evidence, standard and burden of proof. This topic has been hotly debated by the doctrine ${ }^{80}$ and has attracted the attention of both judges Cançado Trindade ${ }^{81}$ and Higgins ${ }^{82}$, who have referred to the IACtHR practice in the matter. In his dissenting opinion in the case Application of the Convention on the Prevention and Punishment of the Crime of Genocide (Croatia v. Servia $)^{83}$, judge Cançado Trindade remarked that the 'absence of direct proof' that the victim suffered cruel and inhuman treatment during the time of detention should not prevent the court from recognizing state responsibility. Referring to IACtHR case law ${ }^{84}$, the judge affirmed that human rights tribunals feel obliged

Human Rights (07 February 2006), paras 5-6; Children and Teenagers deprived of Liberty in the "Complexo do Tatuapé" of FEBEM regarding Brazil Matter (Provisional Measures Order) Inter-American Court of Human Rights (17 November 2005) paras 2-10;

78 Servellón Garcia et al. Case (Merits, Reparations and Costs (Separate opinion of Judge Cançado Trindade) Inter-American Court of Human Rights Series C No 152 (21 September 2006) paras. 7, 17, 24, 26 and 32; IACtHR, The Sawhoyamaxa Indigenous Community Case (Merits, Reparations and Costs Judgment (Separate Opinion Judge Cançado Trindade) Inter-American Court of Human Rights Series C No 146 (29 March 2016), paras. 14.

79 Anne Peters, "Vulnerability"versus "Plausability": Righting or Wronging the Regime of Provisional Measures? Relfections on ICJ, Ukraine v. Russian Federation, Order of 19 April 2017’(EJIL: Talk!, 5 May 2017). https://www.ejiltalk.org/vulnerability-versus-plausibilityrighting-or-wronging-the-regime-of-provisional-measures-reflections-on-icj-ukraine-v-russianfederation-order-of-19-apr/ accessed 18 December 2018.

80 TEITELBAUM, 2007, p. 119; KLEIN, 1996, p. 329; FOSTER, 2011; LACHS, 1993, p. 205; PAYNE, 2011, p. 1191; MALINTOPPI, 2016, p. 421; LIMA, 2015, p. 621; MBENGUE, 2011, p. 53; MBENGUE, 2016, p. 529.

81 Judgment No. 2867 of the Administrative Tribunal of the International Labour Organization upon a Complaint Filed against the International Fund for Agricultural Development (Advisory Opinion (Separate Opinion of Judge Cançado Trindade) General List No 146 [2012] ICJ, 51, paras 67, 75, 91, 96-99; Jurisdictional Immunities of the State (Germany v. Italy: Greece intervening) (Merits (Dissenting Opinion of Judge Cançado Trindade) General List No 143 [2012] ICJ, p. 179, paras 61, 62, 65, 77, 205-211, 216-217, 242, 247.

82 Oil Platforms (Islamic Republic of Iran v. United States of America) (Merits (Separate Opinion of Judge Higgins) General List No 90 [2003] ICJ

83 Application of the Convention on the Prevention and Punishment of the Crime of Genocide (Croatia v. Serbia) (Merits (Dissenting Opinion of Judge Cançado Trindade) General List No 118 [2015] ICJ, p. 202, paras

84 For a collective analysis of the case law of the ICTR and the ICTY, as well as of the Inter-American Court of Human Rights (IACtHR), see Application of the Convention on the Prevention 
to resort, even more forcefully, to presumptions and inferences whenever 'the cases lodged with them disclose a pattern of widespread and systematic gross violations of human rights's5.

Judge Cançado Trindade was not the sole ICJ judge to have issued a separate opinion regarding evidence and burden of proof. There are other examples from judge Higgins, Oil Platforms case ${ }^{86}$, and judge Kreka, in Legality of use of force case ${ }^{87}$. Indeed, the debate concerning the Court's power to draw adverse inferences towards non-production of documents dates back to the Genocide cases ${ }^{88}$ and has continued to take place in ICJ current practice, such as in the recent Road and Certain Activities cases ${ }^{89}$. To date, the ICJ has taken

and Punishment of the Crime of Genocide (Croatia v. Serbia) (Merits (Dissenting Opinion of Judge Cançado Trindade) General List No 118 [2015] ICJ para. 98-115. See also James Gerard Devaney, 'Fact-Finding before the International Court of Justice' (Cambridge University Press 2016), 181.

85 Application of the Convention on the Prevention and Punishment of the Crime of Genocide (Croatia v. Serbia) (Merits (Dissenting Opinion of Judge Cançado Trindade) General List No 118 [2015] ICJ para. 123.

86 Oil Platforms (Islamic Republic of Iran v. United States of America) (Merits (Separate Opinion of Judge Higgins) General List No 90 [2003] ICJ, p. 225, para 33.

87 Legality of Use of Force (Serbia and Montenegro $v$. United Kingdom) (Preliminary Objections (Separate Opinion of Judge ad hoc Kreca) General List No 113 [2004] ICJ; Legality of Use of Force Case (Serbia and Montenegro v Portugal) (Preliminary Objections (Separate Opinion of Judge ad hoc Kreca) General List no 111 [2004] ICJ; Legality of Use of Force Case (Serbia and Montenegro $v$ Netherlands) (Preliminary Objections (Separate Opinion of Judge ad hoc Kreca) General List No 110 [2004] ICJ; Legality of Use of Force (Serbia and Montenegro $v$ Italy) (Preliminary Objections (Separate Opinion of Judge ad hoc Kreca) General List No 109 [2004] ICJ; Legality of Use of Force (Serbia and Montenegro $v$ Germany) (Preliminary Objections (Separate Opinion of Judge ad hoc Kreca) General List No 108 [2004] ICJ; Legality of use of Force Case (Serbia and Montenegro v France) (Preliminary Objections (Separate Opinion of Judge ad hoc Kreca) General List No 107 [2004] ICJ; Legality of Use of Force Case (Serbia and Montenegro $v$ Belgium) (Preliminary Objections (Separate Opinion of Judge ad hoc Kreca) General List No 105 [2004] ICJ, para 10.

88 In the first Genocide case, Bosnia and Herzegovina affirmed that Serbia and Montenegro had a special duty of diligence in preventing genocide and that the proof of its lack of diligence could be inferred from fact and circumstantial evidence (Reply of Bosnia and Herzegovina, in Application of the Convention on the Prevention and Punishment of the Crime of Genocide (Bosnia and Herzegovina $v$ Serbia and Montenegro) Merits (Separate Opinion of Judge ad hoc Kreca) General List No 91 [2007] ICJ, Rep 43, 839, para 22). Serbia and Montenegro had considered parts of relevant documents as being classified. In its judgment, the Court concluded that Serbia and Montenegro failed to prevent the genocide in Srebrenica, without it having had recourse to indirect proof or inferences (Application of the Convention on the Prevention and Punishment of the Crime of Genocide (Croatia v Serbia) Merits) General List No 118 [2015] ICJ Rep 3). The second Genocide case, opposing Croatia to Serbia, followed the same path, as the Court did not deviate from its ruling of 2007 in matters related to evidence (Application of the Convention on the Prevention and Punishment of the Crime of Genocide (Bosnia and Herzegovina $v$ Serbia and Montenegro) Merits (Separate Opinion of Judge ad hoc Kreca) General List No 91 [2007] ICJ, Rep 43, 129, para 206). In these cases, although the situation was perfectly justifiable, the Court did not draw any adverse inference from refusals to reply to a request for information under Article 49 of its Statute.

89 First round of argument by Costa Rica in Certain Activities carried out by Nicaragua in the 
a soft stance towards nonproduction, without shifting the burden of proof or making adverse findings of fact ${ }^{90}$. This position has been attracting the attention of the legal doctrine (such as the International Law Commission) and other ICJ Judges, in particular Judge Mahiou since the first Genocide case ${ }^{91}$. Arguably, in cases involving grave violations of human rights and humanitarian law, the Court should make greater use of its powers to obtain evidence and engage actively with any objection to disclosure of documents before $\mathrm{it}^{92}$, as inspired by IACtHR practice.

\section{D) INTERPRETATION OF HUMAN RIGHTS TREATIES}

A similar argument applies to human rights treaties - forth issue -, which are to be interpreted differently from other multilateral or traditional type treaties. According to Judge Cançado Trindade, the special nature of human rights treaties requires 'proper interpretation', in line with their context and purpose, in order to ensure their 'effet utile"93. In the Kosovo advisory opinion, the Judge cited the Moiwana Community case to uphold the centrality position of victims of human cruelty $^{94}$. He constantly refers to the principle of humanity, as brought before

Border Area (Costa Rica v Nicaragua); Construction of a Road in Costa Rica Along the San Juan River (Nicaragua v Costa Rica), CR 2015/3, 63, para 35. Another example would be the United States Diplomatic and Consular Staff in Tehran (United States of America v Iran) (Judgment) ICJ Reports 1980, 10. For an analysis of other cases in which the Court has avoided making use of indirect reference by drawing inferences, see Ruth Teitelbaum, 'Recent FactFinding Developments at the International Court of Justice' [2007] 6 The Law and Practice of International Court and Tribunals, 136-137. See also Loretta Malintoppi, 'Fact Finding and Evidence Before the International Court of Justice (Notably in Scientific-Related Disputes)' [2016] 7 Journal of International Dispute Settlement, 425.

90 SCHARF and DAY, 2012, p. 128.

91 Application of the Convention on the Prevention and Punishment of the Crime of Genocide (Bosnia and Herzegovina $v$ Serbia and Montenegro) Merits (Separate Opinion of Judge ad hoc Kreca) General List No 91 [2007] ICJ, Rep 43, para 59.

92 Application of the Convention on the Prevention and Punishment of the Crime of Genocide (Bosnia and Herzegovina $v$ Serbia and Montenegro) Merits (Separate Opinion of Judge ad hoc Kreca) General List No 91 [2007] ICJ, Rep 43, para 59.

93 Alleged Violations of Sovereign Rights and Maritime Spaces in the Caribbean Sea (Nicaragua v. Colombia) (Merits (Separate Opinion of Judge Cançado Trindade) General List No 155 [2016] ICJ, para 5, 16, 22, 24, 42-45, 50, 65-66, 71. For the application of the principle of Humanity supported by IACtHR's case law references, see also Judge Cançado Trindade's Dissenting Opinions on Obligations concerning Negotiations relating to Cessation of the Nuclear Arms Race and to Nuclear Disarmament (Marshall Islands v United Kingdom) (Preliminary Objections (Dissenting Opinion of Judge Cançado Trindade) General List No 160 [2016] ICJ; Obligations concerning Negotiations relating to Cessation of the Nuclear Arms Race and to Nuclear Disarmament (Marshall Islands v Pakistan) (Preliminary Objections (Dissenting Opinion of Judge Cançado Trindade) General List No 159 [2016] ICJ; Obligations concerning Negotiations relating to Cessation of the Nuclear Arms Race and to Nuclear Disarmament (Marshall Islands v India) (Preliminary Objections (Dissenting Opinion of Judge Cançado Trindade) General List No 158 [2016] ICJ.

94 Accordance with International Law of the Unilateral Declaration of Independence in Respect of Kosovo (Advisory Opinion (Separate Opinion of Judge Cançado Trindade) General List No 
the IACtHR, which should be applied 'even more forcefully' in the treatment of persons in situation of special vulnerability, as stated in his opinion in the Genocide case (Croatia v. Serbia) ${ }^{95}$.

In the Preliminary Objections on the case Application of the International Convention on the Elimination of All Forms of Racial Discrimination (Georgia v. Russia Federation $)^{96}$, Judge Cançado Trindade states his 'entirely dissenting opinion on the whole matter', based on IACtHR jurisprudence. Guided by a distinct interpretation of Article 22 of the CERD (compromissory clause), Judge Cançado Trindade considered that the Court had jurisdiction to entertain the case because of the fundamental character of the clause pertaining to the compulsory jurisdiction of international human rights tribunals combined with the nature and substance of the CERD Convention ${ }^{97}$.

Besides Judge Cançado's contribution, in the Joint Opinion by Judges Higgins, Kooijmans, Elaraby, Owada and Simma in the admissibility judgment on the Armed Activities on the Territory of the Congo case (Democratic Republic of the Congo v. Rwanda), the Judges cited the IACtHR Advisory Opinion No. 2 and 3, along with the UN Human Rights Committee, which is opposite to ICJ's majority judgment that denies any human rights 'special' interpretation ${ }^{98}$.

141 [2010] ICJ, paras 163-164, 209.

95 Application of the Convention on the Prevention and Punishment of the Crime of Genocide (Croatia v. Serbia) (Merits (Dissenting Opinion of Judge Cançado Trindade) General List No 118 [2015] ICJ p. 202, para 70, 77, 79, 83. Plan de Sánchez Massacre Case (Merits Judgment (Separate Opinion of Judge Cançado Trindade) Inter-American Court of Human Rights Series C No 105 (29 April 2004) one of a pattern of 626 massacres; Maritza Urrutia Case (Merits Judgment (Separate Opinion of Judge Cançado Trindade) Inter-American Court of Human Rights Series C No 103 (27 November 2003), para. 87; Juan Humberto Sánchez Case (Preliminary Objections, Merits, Reparations and Costs (Separate Opinion of Judge Cançado Trindade) Inter-American Court of Human Rights Series C No 99 (7 June 2003), para. 96; Cantoral Benavides Case (Merits Judgment (Separate Opinion of Judge Cançado Trindade) Inter-American Court of Human Rights Series C No 69 (18 August 2000), para 90; and Bámaca Velásquez Case (Merits Judgment (Separate Opinion of Judge Cançado Trindade) InterAmerican Court of Human Rights Series C No 70 (25 November 2000), para. 150.

96 Application of the International Convention on the Elimination of All Forms of Racial Discrimination (Georgia v. Russian Federation) (Preliminary Objections (Dissenting Opinion of Judge Cançado Trindade) General List No 140 [2011] ICJ, p.239, paras 69, 72.

97 Application of the International Convention on the Elimination of All Forms of Racial Discrimination (Georgia v. Russian Federation) (Preliminary Objections (Dissenting Opinion of Judge Cançado Trindade) General List No 140 [2011] ICJ, p.239, paras 177-178, 180. Also in this sense, the Whaling case, making reference to the IACtHR case of Mayagna (Sumo) Awas Tingni Community v. Nicaragua and the Advisory Opinion on the right to information on consular assistance. Whaling in the Antarctic Case (Australia v Japan: New Zealand intervening) (Merits (Separate Opinion of Judge Cançado Trindade) General List No 148 [2014] p. 348, para 32.

98 Armed Activities on the Territory of the Congo (Democratic Republic of the Congo v. Rwanda) (Preliminary Objections (Joint Separate Opinion of Judges Higgings, Kooijmans, Elaraby, Owada and Simma) General List No 126 [2006] ICJ, p. 65, 12, 15, 16. 


\section{E) MATERIAL SCOPE OF JUS COGENS}

Another issue that has not actually influenced the understanding of ICJ majority Judges is the expansion of the material scope of jus cogens, in line with IACtHR case law, as argued by Judge Cançado Trindade in his opinions. The jus cogens character of the prohibition of torture ${ }^{99}$ and of the principle of 'non-discrimination' ${ }^{100}$ constitute examples of the enlargement of the material content of jus cogens, which is duly supported by the IACtHR case law brought before the Court by Judge Cançado Trindade. For instance, the Judge referred to IACtHR case law, in particular the Advisory Opinion of the Juridical Condition and Rights of Undocumented Migrants ${ }^{101}$, both in the Preliminary Objections in the case Georgia v. Russian Federation (2011) ${ }^{102}$ and in the order on Provisional Measures in the case Qatarv. United Arab Emirates $(2018)^{103}$, in order to reaffirm the jus cogens character of the principle of equality and non-discrimination. These cases dealt with the International Convention on the Elimination of All Forms of Racial Discrimination (CERD), such as the Ukraine v. Russian Federation ${ }^{104}$.

\section{F) REPARATIONS}

The separate opinion of Judge Cançado Trindade in the Diallo Case resonated well in the Court's practice, the individual right to reparation, is wellestablished in international human rights law (IACtHR and ECHR) ${ }^{105}$. In his separate opinion opinion on the Judgment on compensation of the Diallo case (2012), Judge Cançado Trindade expressly referred to IACtHR case law from 1998 to 2003 to support a reasoning based on the 'humanization of international

99 Questions relating to the Obligation to Prosecute or Extradite (Belgium v. Senegal) (Provisional Measures Order (Dissenting Opinion of Judge Cançado Trindade) General List No 144 [2009] ICJ, p. 165, para. 66-67.

100 Accordance with International Law of the Unilateral Declaration of Independence in Respect of Kosovo (Advisory Opinion (Separate Opinion of Judge Cançado Trindade) General List No 141 [2010] ICJ, p. 523, para 3-4.

101 Juridical Condition and Rights of Undocumented Migrants, Advisory Opinion OC-18, InterAmerican Court of Human Rights Series A No 18 (17 September 2003).

102 Application of the International Convention on the Elimination of All Forms of Racial Discrimination (Georgia $v$ Russian Federation) (Preliminary Objections (Dissenting Opinion of Judge Cançado Trindade) General List No 140 [2011] ICJ.

103 Application of the International Convention on the Elimination of all forms of racial discrimination (Qatar $v$ United Arab Emirates) (Provisional Measures Order (Separate Opinion of Judge Cançado Trindade) General List No 172 [2018] ICJ p. 6, para 19.

104 Application of the International Convention for the Suppression of the Financing of Terrorism and of the International Convention on the Elimination of All Forms of Racial Discrimination (Ukraine v. Russian Federation) (Provisional Measures Order (Separate Opinion of Judge Cançado Trindade) General List No 166 [2017] ICJ, p. 104.

105 Abmadou Sadio Diallo (Republic of Guinea v. Democratic Republic of the Congo) (Compensation (Separate Opinion of Judge Cançado Trindade) General List No 103 [2012] ICJ p. 372 para 64: Other contemporary international tribunals have much to benefit from the experience gathered in this specific domain, in being attentive to it and taking it into due account [...]'. 
law' ${ }^{106}$. The IACtHR has engaged in an innovative path by establishing distinct forms of reparations, which includes 'restitutio in integrum'; compensation; victim satisfaction; victim rehabilitation; acts of public apology; guarantees of non-repetition; and others. According to the Judge, the aspects and modalities of reparation are to be the determined by IACtHR standards and not by domestic law, as recognized by its case law ${ }^{107}$.

The Lozaya Tomayo v. Peru and Cantoral Benavides v. Peru case was referred to by Judge Cançado Trindade with a view to support the connection between reparation and damage to the victim's life project, including needs and aspirations. Along the same line, the reparations ordered in the cases of massacres included heath, housing, education and human development initiatives ${ }^{108}$. Conversely, reparations also present a 'collective dimension', as recognized in the cases involving indigenous communities: reparation may take the form of acts to 'honour the memory of the victims' ${ }^{109}$ or to 'the right to truth" ${ }^{110}$. Judge Cançado Trindade also cited IACtHR case law to assert the importance of restorative justice

106 Abmadou Sadio Diallo (Republic of Guinea v. Democratic Republic of the Congo) (Compensation (Separate Opinion of Judge Cançado Trindade) General List No 103 [2012] ICJ p. 371, para 60 .

107 See "Street Children” Case (Reparations and Costs Judgment) Inter-American Court of Human Rights Series C No 177 (26 May 2001).

108 Aloeboetoe et al. Case (Reparations and Costs Judgment) Inter-American Court of Human Rights Series C No 15 (10 September 1993); Plan de Sánchez Massacre Case (Merits Judgment (Separate Opinion of Judge Cançado Trindade) Inter-American Court of Human Rights Series C No 105 (29 April 2004); The Massacres of Ituango Case (PReliminary Objections, Merits, Reparations and Costs) Inter-American Court of Human Rights Series C No 148 (1 July 2006).

109 Bámaca Velásquez Case (Reparations and Costs Judgment) Inter-American Court of Human Rights Series C No 91 (22 February 2002); Myrna Mack Chang Case (Merits, Reparations and Costs) Inter-American Court of Human Rights Series C No 101 (25 November 2003); Moiwana Community Case (Preliminary, Objetions, Merits, Reparations and Costs) Inter-American Court of Human Rights Series C No 124 (15 June 2005); Trujillo Oroza Case (Reparations and Costs) Inter-American Court of Human Rights Series C No 92 (27 February 2002); Plan de Sánchez Massacre Case (Reparations Judgment) Inter-American Court of Human Rights Series C No 116 (19 November 2004). In this last and dramatic case, those acts were to be accompanied (as they in fact were) by social programmes (rehabilitation) for the members of the affected community.

110 Bulacio Case (Merits, Reparations and Costs) Inter-American Court of Human Right Series C No 100 (19 September 2003); Bámaca Velásquez Case (Reparations and Costs) Inter-American Court of Human Rights Series C No 91 (22 February 2002); El Caracazo Case (Reparations and Costs) Inter-American Court of Human Rights Series C No 95 (29 August 2002), as well as in the cases of Barrios Altos Case (Merits) Inter-American Court of Human Rights Series C No 87 (14 March 2001), and of the "Juvenile Reeducation Institute"Case (Preliminary, Objections, Merits, Reparations and Costs) Inter-American Court of Human Rights Series C No 112 (2 September 2004). Moreover, in its judgmenets in the aforementioned case of Bámaca Velásquez Case (Merits) Inter-American Court of Human Rights Series C No 70 (25 November 2000) and Bámaca Velásquez Case (Reparations and Costs) Inter-American Court of Human Rights Series C No 91 (22 February 2002) as well as in that of the 19 Merchants Case (Merits, Reparations and Costs) Inter-American Court of Human Rights Series C No 109 (5 July 2004), the IACtHR dwelt upon the right to truth as a measure of reparation. 
with a 'rehabilitation' of victims, which can include medical and psychological assistance for victims of grave violations of personal integrity ${ }^{111}$. More recently, on the Compensation Judgment in the Certain Activities case, Judge Cançado Trindade cited the IACtHR case law to address the matter of reparations ${ }^{112}$. He stressed that there is no hierarchy between the distinct forms of reparations, these being complementary and applied according to the circumstances of the case at hand, as acknowledged by the IACtHR in the Street Children case ${ }^{113}$.

\section{CONCLUSION}

The ICJ has been reticent in following the path of other ICTs as far as cross-referencing is concerned. While the IACtHR extensively refers to other Courts, the ICJ remains cautious in the process of importation of precedents from other ICTs, notably from the IACtHR. Nonetheless, the ICJ's openness to judicial dialogue corresponds to the World Court's recent concern with human rights. The Diallo case, that marked the apogee of human rights protection at the ICJ, represents the sole example of direct judicial dialogue with the IACtHR in a majority judgment.

Reference to IACtHR case law provided guidance and inspiration for the solution of a legal problem, in particular, to determine the amount of compensation. Not surprisingly, the ICJ has generally avoided open reference to regional human rights tribunals in majority judgments. This is maybe be due to the lack of common judicial identity, along with historical and cultural traditions of avoiding referral to external case law ${ }^{114}$. However, most references to IACtHR case law are found in the individual opinions of judges with emphasis to judge Cançado Trindade.

There is no doubt that judicial dialogue is capable of fostering integration and normative coherence on a global scale ${ }^{115}$. Therefore, judicial dialogue facilitates the integration and application of human rights law, in particular within the ICJ.

\section{REFERÊNCIAS}

ALMEIDA, Paula Wojcikiewicz. The legitimacy of International Trade Tribunals: the case of Mercosur. In: RUIZ-FABRI, H; ULFSTEIN, G; HOWSE, R. The

111 "Street Children" Case (Reparations and Costs Judgment) Inter-American Court of Human Rights Series C No 77 (26 May 2001), para. 22.

112 Certain Activities carried out by Nicaragua in the Border Area (Costa Rica v Nicaragua) (Compensation (Separate Opinion of Judge Cançado Trindade) General List No 150 [2018] ICJ, 35-37.

113 "Street Children" (Villagrán-Morales et al.) Case (Reparations and Costs) Inter-American Court of Human Rights Series C No 77 (26 May 2001), paras 98.

114 SLAUGHTER, 1994, p. 119.

115 MAC-GREGOR, 2017, p. 96. 
Legitimacy of International Trade Tribunals, Cambridge University Press, 2019. BUERGENTHAL, Thomas; NORRIS, Robert; SHELTON, Dinah. Protecting Human Rights in the Americas, Selected Problems. N. P. Engel Publisher, 2 ed., 1986.

CROOK, John R. The International Court of Justice and Human Rights. Northwestern Journal of International Human Rights, v. 1, 2004.

DE BRABANDERE, Eric. The Use of Precedent and External Case-Law by the International Court of Justice and the International Tribunal for the Law of the Sea. The Law and Practice of International Courts and Tribunals, v. 15, n.1, 2016.

EL BOUDOUHI, Saïda. L'arrêt Ahmadou Sadio Diallo (République de Guinée c. République démocratique du Congo). La CIJ est-elle devenue une juridiction de protection des droits de l'homme? Annuaire français de droit international, v. $56,2010$.

FOSTER, Caroline E. Science and the Precautionary Principle in International Courts and Tribunals. Expert Evidence, Burden of Proof and Finality. Cambridge University Press, 2011.

GIORGETTI, Chiara. Introductory Note the International Court of Justice: Ahmadou Sadio Diallo (Republic of Guinea v. Democratic Republic of the Congo) Compensation owed by the Democratic Republic of the Congo to the Republic of Guinea. International Legal Materials, v. 51, 2012.

HIGGINS, Rosalyn. Human Rights in the International Court of Justice. Leiden Journal of International Law, V. 20, 2007.

HOSS, Cristina. The forgotten case of Angel Francisco Breard. In: ALMEIDA, Paula Wojcikiewicz; SOREL, Jean-Marc (eds), Latin America and the ICJ: Contributions to International law. Routledge, 2016.

KLEIN, Natalie S. Multilateral Disputes and the Doctrine of Necessary Parties in the East Timor Case. Yale Journal of International Law, v. 21, n. 2, 1996.

$\mathrm{KOH}$, Harold. International Law as Part of Our Law. American Journal of International Law, v.98, 2004.

LACHS Manfred H. Evidence in the Procedure of the International Court of Justice: Role of the Court. In: BELLO, Emmanuel G; AJIBOLA, Bolasodun A. (orgs.) Essays in Honour of Judge Taslim Olawale Elias, Martinus Nijhoff, 1993.

LAW, David S. Law; CHANG, Wen-Chen. The Limits of Global Judicial Dialogue. Washington Law Review, v. 86, n.3, 2011.

LIMA, Lucas Carlos. The Evidential Weight of Experts before the ICJ: Reflections on the Whaling in the Antarctic Case. Journal of International Dispute Settlement, v. 6, 2015. 
MAC-GREGOR, Eduardo Ferrer. What Do We Mean When We Talk about Judicial Dialogue: Reflections of a Judge of the Inter-American Court of Human Rights. Harvard Human Rights Journal, v. 30, 2017.

MALINTOPPI, Loretta. Fact Finding and Evidence Before the International Court of Justice (Notably in Scientific-Related Disputes). Journal of International Dispute Settlement, v. 7, 2016.

MBENGUE, Makane Moïse. International Courts and Tribunals as Fact-Finders: The Case of Scientific Fact-Finding in International Adjudication. Loyola of Los Angeles International and Comparative Law Review, v. 34, n.1, 2011.

NEUMAN, Gerald L, The External Reception of Inter-American Human Rights Law Special Edition Quebec Journal of International Law, 2011.

NUBBERGER, Angelika. 'The ECtHR' use of decisions of International Courts and Quasi-Judicial Bodies. In: MÜLLER, Amrei (org.). Judicial Dialogue and Human Rights, Studies on International Courts and Tribunals, Cambridge University Press, 2017.

PASQUALUCCI, Jo M. The Inter-American Human Rights System: Establishing Precedents and Procedure in Human Rights Law. Inter-American Law Review, v. 26, 1995.

PAYNE, Cymie. Mastering the Evidence: Improving Fact Finding by International Courts. Environmental Law Review, v. 41, 2011.

PETERS Anne. "Vulnerability" versus "Plausability": Righting or Wronging the Regime of Provisional Measures? Reflections on ICJ, Ukraine v. Russian Federation, Order of 19 April 2017. EJIL: Talk! Disponível em: <https://www. ejiltalk.org/vulnerability-versus-plausibility-righting-or-wronging-the-regime-ofprovisional-measures-reflections-on-icj-ukraine-v-russian-federation-order-of-19apr/. Acesso em 18 de dezembro de 2018.

SCHARF, Michael P.; DAY, Margaux. The International Court of Justice's Treatment of Circumstantial Evidence and Adverse Inferences. Chicago Journal of International Law, v. 13, n.1, 2012.

SIMMA, Bruno. Human Rights before the International Court of Justice: Community Interest Coming to Life? In: TAMS, Christian J, Development of International Law by the International Court of Justice. Oxford University Press, 2013.

SLAUGHTER, Anne-Marie. A Global Community of Courts. Harvard International Law Journal, v. 44, n.1, 2003.

SLAUGHTER, Anne-Marie, A Typology of Transjudicial Communication, University of Richmond Law Review, v. 29, n. 1, 1994.

TEITELBAUM, Ruth. Recent Fact-Finding Developments at the International 
Court of Justice. The Law and Practice of International Court and Tribunals, v. 6, 2007.

TZANAKOPOULOS, Antonios. Judicial Dialogue as a Means of Interpretation. In: AUST, Helmut Philip; NOLTE, Georg (eds), The Interpretation of International Law by Domestic Courts: Uniformity, Diversity, Convergence. Oxford University Press, 2016.

ULFSTEIN Geir. Awarding Compensation in a Fragmented Legal System: the Diallo Case. Journal of International Dispute Settlement, v. 4, n.3, 2013.

VOETEN, Erik, Borrowing and Nonborrowing among International Courts. The Journal of Legal Studies, v. 39, 2010.

ZYBERI, Gentian. The International Court of Justice and applied forms of reparation for international human rights and humanitarian law violations. Utrecht Law Review, v. 71, n.1, 2011.

\section{AGRADECIMENTOS}

Agradecimentos especiais à Gabriela Hünhe Porto, assistente de pesquisa da Cátedra Jean Monnet da FGV DIREITO RIO e mestranda em Direito Internacional pela UERJ, pela extensa pesquisa realizada e pelos esforços envidados para a conformação final do presente artigo.

Recebido em: 15/04/2019.

Aprovado em: 30/08/2019. 


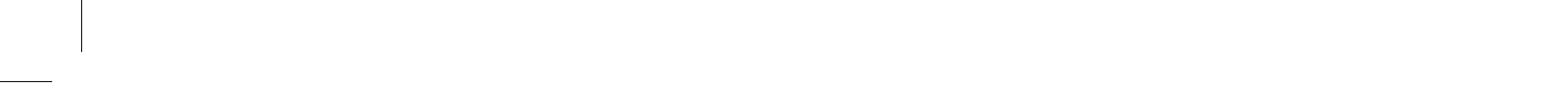

